\title{
Disruptive coloration and habitat use by seahorses
}

\author{
Michele Duarte ${ }^{1}$, Felipe M. Gawryszewski², Suzana Ramineli ${ }^{3}$ and Eduardo Bessa ${ }^{1,4}$
}

Predation avoidance is a primary factor influencing survival. Therefore, any trait that affects the risk of predation, such as camouflage, is expected to be under selection pressure. Background matching (homochromy) limits habitat use, especially if the habitat is heterogeneous. Another camouflage mechanism is disruptive coloration, which reduces the probability of detection by masking the prey's body contours. Here we evaluated if disruptive coloration in the longsnout seahorse, Hippocampus reidi, allows habitat use diversification. We analyzed 82 photographs of animals, comparing animal and background color, and registering anchorage substrate (holdfast). We tested whether the presence (disruptive coloration) or absence of bands (plain coloration) predicted occupation of backgrounds of different colors. We also calculated the connectance between seahorse morph and background color or holdfast, as well as whether color morph differed in their preferences for holdfast. Animals with disruptive coloration were more likely to be found in environments with colors different from their own. Furthermore, animals with disruptive coloration occupied more diversified habitats, but as many holdfasts as plain colored animals. Therefore, animals with disruptive coloration were less selective in habitat use than those lacking disruptive color patterns, which agrees with the disruptive coloration hypothesis.

Keywords: Camouflage, Hippocampus reidi, Predation, Syngnathidae.

Evitar a predação é um dos principais fatores que influenciam a sobrevivência. Portanto, qualquer traço que afete o risco de predação, como a camuflagem, deverá estar sob forte pressão de seleção. Confundir-se com a cor do fundo (homocromia) limita o uso do habitat, especialmente se ele é heterogêneo. Outro mecanismo de camuflagem é a coloração disruptiva, que reduz a probabilidade de detecção mascarando o contorno do corpo da presa. Aqui nós avaliamos se a coloração disruptiva no cavalo-marinho de focinho comprido, Hippocampus reidi, permite diversificar o uso do habitat. Analisamos 82 fotografias de animais, comparando a cor do animal à do fundo, e registrando o substrato de apoio (holdfast). Nós testamos se a presença (coloração disruptiva) ou ausência de bandas (coloração lisa) predizia a ocupação de substratos de cores diferentes. Nós também calculamos a conectância entre o morfo do cavalo-marinho e a cor do fundo ou o substrato de apoio, bem como se o morfo diferiu em suas preferências por substratos de apoio. Animais com coloração disruptiva eram mais encontrados em ambientes com cores diferentes de sua própria cor. Além disso, os animais com coloração disruptiva ocupavam habitats mais diversificados, mas tantos substratos de apoio quanto animais lisos. Portanto, animais com cores disruptivas eram menos seletivos do que animais lisos quanto ao habitat que utilizavam, o que concorda com a hipótese da coloração disruptiva.

Palavras-chave: Camuflagem, Hippocampus reidi, Predação, Syngnathidae.

\section{Introduction}

The predator-prey relationship is one of the leading forces shaping ecological communities and driving the evolution of adaptations (Van Der Laan, Hogeweg, 1995). The ideal free distribution theory (Fretwell, 1969) predicts that predators will choose environments with food of quality and quantity, although other factors, such as competition and the predator's sensory capacity, should also be taken into account (Kennedy, Gray, 1993). Fish prey, as many other species, employ various strategies to prevent from being preyed on, e.g., producing molecules that make them indigestible (Itoi et al., 2014), being difficult to manipulate by the predator (Ebenstein et al., 2015), fleeing (Ramasamy et al., 2015) or avoiding being detected or recognized (Rouse et al., 2017).

${ }^{1}$ Faculdade de Planaltina, Universidade de Brasília. Área Universitária 1, Bairro Nossa Senhora de Fátima, Planaltina, 73345-010 Brasília, DF, Brazil. (MD) michele.duarte.mds@gmail.com, Ohttps://orcid.org/0000-0003-0340-2980

${ }_{2}^{2}$ Departamento de Zoologia, Universidade de Brasília. Campus Universitário Darcy Ribeiro, Asa Norte, 70910-000 Brasília, DF, Brazil. f.gawry@gmail.com, Dhttps://orcid.org/0000-0002-3072-5518

${ }^{3}$ Projeto Cavalos do Mar. Rua das Flores, 571, Vila Histórica de Mambucaba, 23951-310 Angra dos Reis, RJ, Brazil. cavalosdomar@gmail. com, Dhttps://orcid.org/0000-0002-5734-1442

${ }^{4}$ Programa de Pósgraduação em Ecologia, Universidade de Brasília. Campus Universitário Darcy Ribeiro, Asa Norte, $70910-000$ Brasília, DF, Brazil. (EB) profbessa@unb.br (corresponding author), Ohttps://orcid.org/0000-0003-0606-5860

e190064[1] 
Camouflage may be defined as the set of strategies involved in concealing an animal, including the prevention of both detection and recognition (Stevens, Merilaita, 2009). Camouflage might be divided into different strategies. A common strategy is background matching (also referred to as homochromy or crypsis). It is defined as the type of camouflage in which an animal color, pattern, and brightness are similar to one or several backgrounds (Endler, 1984; Merilaita et al., 1999; Stevens, Merilaita, 2009). Another common strategy is the disruptive coloration, which consists of a pattern of contrasting patches that disguises the contour of the animal, hindering its detection by predators, even if its colors do not perfectly match the background (Cuthill et al., 2005; Stevens et al., 2006; Stevens, Merilaita, 2009). To be effective, the contrasting patterns must reach the animal's body periphery (Cuthill et al., 2005; Webster et al., 2013). Animals as diverse as arthropods, snakes, lizards, fish, and birds present disruptive coloration (Stevens et al., 2006; Leone, 2014). All this diversity of species using disruptive coloration suggests that there are advantages to this strategy.

Disruptive patterns are regarded as less habitat-specific than background matching because disruptive coloration reduces the probability of predation even in non-matching backgrounds (Merilaita, Lind 2005; Stevens et al., 2006), sometimes even more efficiently than background matching (Cuthill et al., 2005). Furthermore, disruptive coloration might allow for maintaining color patterns related to communication (sexual selection, social status) without giving up some degree of camouflage (Stevens et al., 2006), and enabling animals to remain concealed in habitats with different background colors (Schaefer, Stobbe, 2006), similar to what transparent (Carvalho et al., 2006) and colorchanging animals can do (Stevens, 2016). Therefore, it is expected that in environments with high habitat diversity or background colors and with an intense presence of visually oriented predators, numerous species with disruptive coloration will evolve. This is especially expected among those species undefended against predators, non-toxic, and slow organisms.

Seahorses meet the above criteria. They inhabit shallow tropical or warm temperate waters, in reefs, mangroves, estuaries, and bays (Rosa et al., 2002; Dias, Rosa, 2003). The genus Hippocampus is distributed around the world with 42 species (Lourie et al., 2016; Short et al., 2018), of which Hippocampus reidi Ginsburg, 1933 is common in the Brazilian coast (Figueiredo, Menezes, 1985), although two other species, H. erectus Perry, 1810 and H. patagonicus Piacentino \& Luzzatto, 2004, also occur (Silveira et al., 2014). They are demersal and slow-swimming animals that attach to the substrate with a prehensile tail. These animals are a constant target of the aquarium trade (Rosa et al., 2006) and are also used in traditional Chinese medicine (Chen et al., 2015). Hippocampus reidi presents diverse coloration among individuals, including transverse bands that reach the body margin (Lourie et al., 1999), which could be a case of disruptive coloration.
We aimed to evaluate if seahorses benefit from disruptive coloration (Stevens et al., 2006) to occupy their habitat, capitalizing on the existence of plain (without disruptive coloration) and banded (with disruptive coloration) color morphs. Based on the evidence that disruptive coloration is less habitat dependent (hereafter the disruptive coloration hypothesis), we predict that disruptive individuals will occupy diverse substrates and attach to more holdfasts than plain colored individuals.

\section{Material and Methods}

We collected our data at Ilha Grande Bay (Fig. 1), located in Rio de Janeiro, Brazil. This bay covers Angra dos Reis and Paraty municipalities, occupying an area of $1728 \mathrm{~km}^{2}$ and about $356 \mathrm{~km}$ of waterline perimeter (Pinto-Joventino et al., 2013). Situated between the meridians $44^{\circ}$ and $44^{\circ} 40^{\prime} \mathrm{W}$ and latitudes $23^{\circ}$ and $23^{\circ} 40^{\prime} \mathrm{S}$ (Belo et al., 2002), Ilha Grande Bay's islands, beaches, mangroves and rocky shores are of paramount importance because they are included in the Atlantic Forest, a biodiversity hotspot (MMA, 2003; Creed et al., 2007). Despite the heavy rainfall, water in Ilha Grande Bay is clear for most of the year.

Only $H$. reidi, which is the most abundant species in our study area (Suzana. Ramineli, 2019 pers. obs.) and whose habitat is consistent with the description in Silveira et al. (2014), was observed. Hippocampus erectus and $H$. patagonicus also occur in the area. Hippocampus reidi was identified based on the long snout, crown, spot pattern and dorsal fin spines (Lourie et al., 1999). We collected data from 96 seahorse photos, from which we selected 82 images according to the following criteria: seahorse color and morph was unambiguous, and animals were clearly visible. Photos were taken during the day between 2014 and 2018 as part of the monthly monitoring of Ilha Grande Bay carried out by the Projeto Cavalos do Mar, a Brazilian group of Syngnathidae researchers, without any capture, manipulation or disturbance of the animals. During our study, no animal was killed or harmed, which is in accordance with animal welfare regulations. Similarly, we applied no image treatment to the photos we used. Recollection of data from the same individual was avoided by using photos from different collect sites, years, seahorse sex, size and coronet pattern, since individuals can be visually recognized (Freret-Meurer et al., 2013).

We collected information on seahorse body-color, color morph, substrate color and holdfast for each animal in the selected photos. We used body-color categories (yellow, orange, red, black, brown) according to the literature (Perante et al., 2002; Dias, Rosa, 2003). Although body color change was previously reported in the Hippocampus genus (Foster, Vincent, 2004; Qin et al., 2012) the banded pattern in $H$. reidi does not change (Suzana Ramineli, 2019 pers. obs.). We also classified the seahorses by color morph as disruptive (presence of transversal bands) or plain (absence of bands), which cannot appear or disappear if body color changes. We calculated the percentage of individuals of each color and 


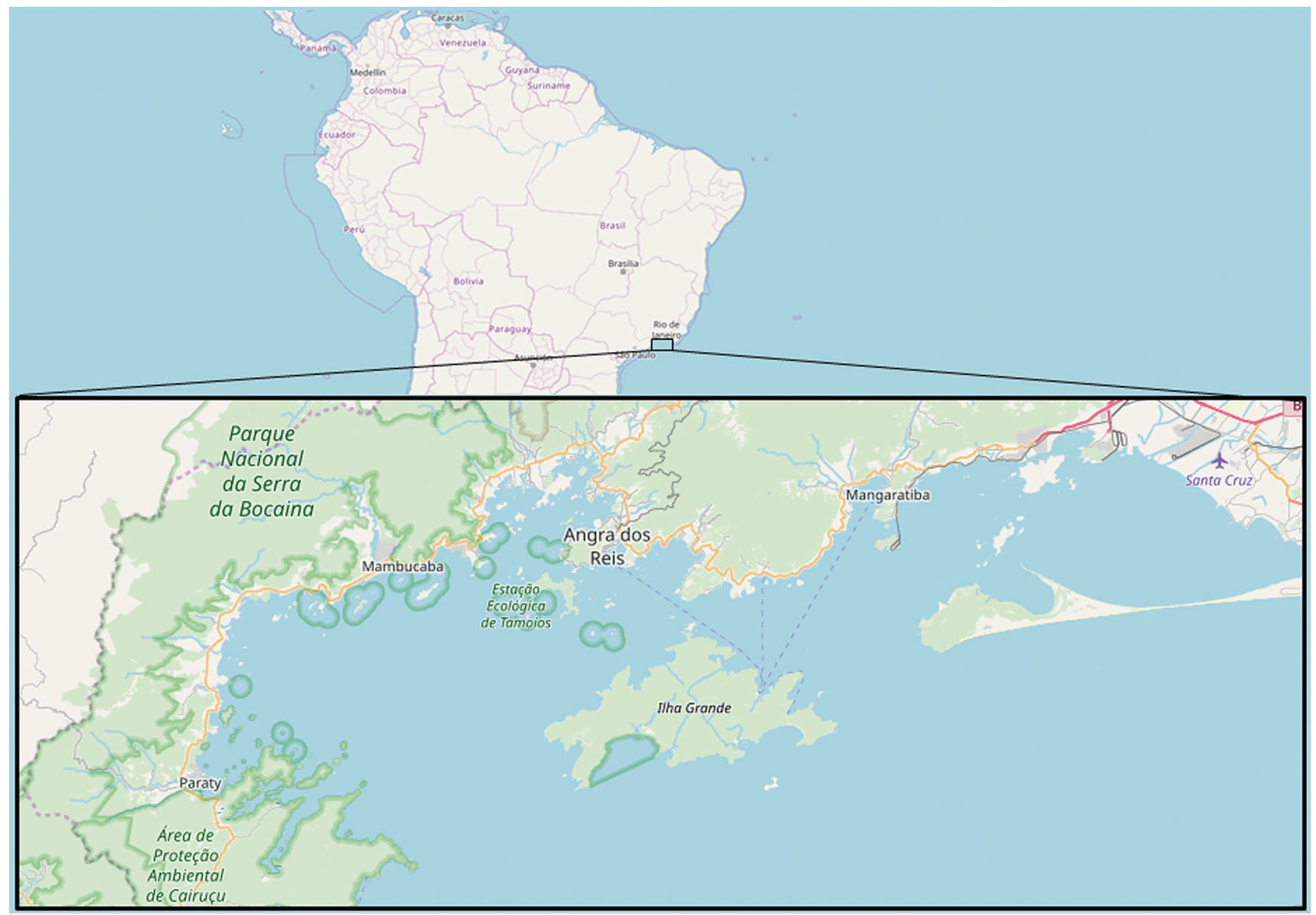

Fig. 1. Study area in Ilha Grande Bay, Rio de Janeiro, Brazil (Image source: Infraestrutura Nacional de Dados Espaciais CC-BY 3.0).

color morph in the population. Finally, we registered holdfast categories (superior plants, corals, sponges, macroalgae and sand) and predominant color of the substrate (yellow, white, orange, brown, black, pink, purple, green or red).

We then evaluated: I) if disruptive colored individuals were connected to more background colors and holdfasts using a connectance index (a function of how many background colors or holdfasts do a morph occupy divided by the total number of background colors or holdfasts there are available); II) The frequency that an animal of each color morph was found matching its body color to the background color; III) If the different color morphs presented a preference for holdfast using a chi-square test; and IV) whether the probability of finding a seahorse matching body color and background color was explained by the presence of bands (disruptive coloration) by using a generalized linear model (GLM) with binomial distribution (logit link function).

For the chi-square test, we considered the number of images each seahorse was photographed on each holdfast as observed values, while the expected values were proportional to the availability of that holdfast in all the images. For the GLM test, we set the dependent variable to zero when the seahorse and background color matched, and set it to one when seahorse and background color differed. Presence of bands (disruptive coloration) entered as the independent variable. We compared the full model against a null model (model with the intercept only) using a chi-square test (i.e., log-likelihood ratio test). We visually validated the GLM model using Pearson residuals vs. fitted and independent variables, and by comparing these plots to simulated data (Loy et al., 2017). GLM test was performed in R (version 3.5.0).

\section{Results}

There were more disruptive colored individuals $(\mathrm{N}=49 / 82 ; 60 \%)$ than plain colored individuals $(\mathrm{N}=33 / 82$; $40 \%$ ). The predominant body color was yellow, followed by brown and orange (Fig. 2). Disrupted colored seahorses occupy all background colors and attach to all holdfasts available (Fig. 3), while plain seahorses do not attach to pink or purple substrates or to superior plants. Some examples of plain and disruptive seahorses in their background color and holdfasts are provided in Fig. 4. Similarly, in $70 \%$ of the photographs, plain seahorses matched their body color to that of the substrate, while only $4 \%$ of the disruptive colored individuals did so. This can also be observed by the proportion of animals placed on substrate of a different color from their bodies (Fig. 5). 


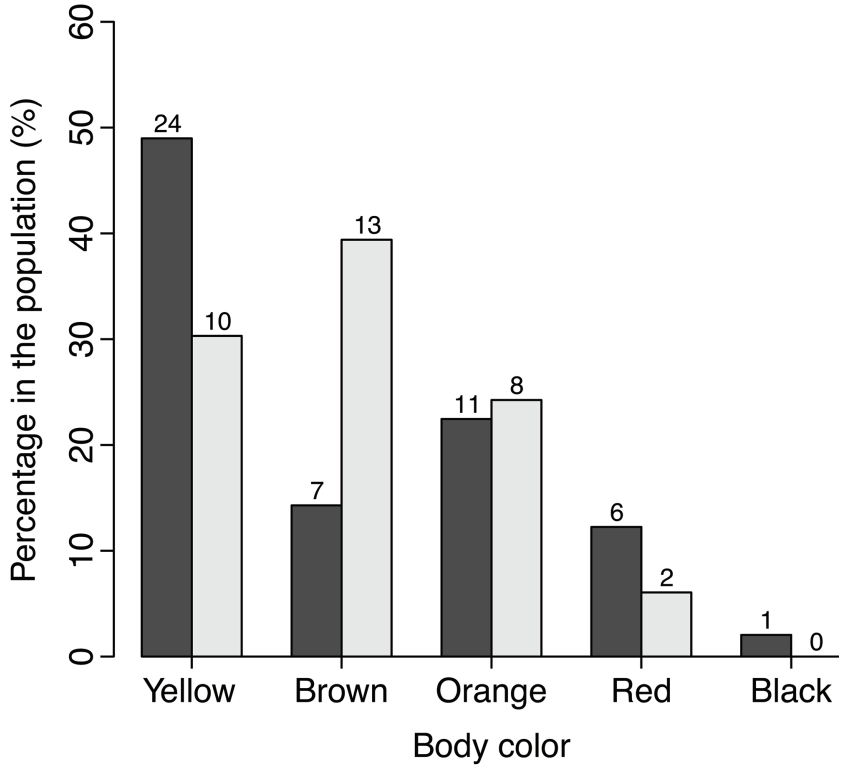

Fig. 2. Percentage of occurrence of body-color for each color morph of Hippocampus reidi (dark colored bars: disruptive morph; light-colored bars: plain morph). Tags above each column indicate the absolute number of individuals.

According to the chi-square test, plain and disruptive colored seahorses randomly attached to holdfasts (chi-square test: deviance difference $e_{\text {plain }}=3.4162 ; \mathrm{DF}_{\text {plain }}=4 ; \mathrm{p}_{\text {plain }}=0.3229$; deviance difference $_{\text {dissuptive }}=2.3007 ; \mathrm{DF}_{\text {disruptive }}=4 ; \mathrm{p}_{\text {disruptive }}=$ $0.9968)$. Nonetheless, the probability of finding a seahorse in a background different from its own was significantly higher when the seahorse presented disruptive coloration $(95 \% \mathrm{CI}=$ $98-85 \%)$ than when it presented a plain coloration $(95 \% \mathrm{CI}=$ 48-17\%; chi-square test: deviance difference $=43.653 ; \mathrm{DF}=1$; $\mathrm{p}<0.0001 ; \quad$ Estimate $\pm \mathrm{SE}_{\text {intercept }}=-0.83 \pm 0.38 ; \quad \mathrm{z}$ - value $_{\text {intercept }}$ $=-2.199 ; \quad \mathrm{p}_{\text {intercept }}=0.0279 ; \quad$ Estimate $\pm \mathrm{SE}_{\text {disruptive }}=3.99 \pm 0.82$; z-value $\left._{\text {intercept }}=4.895 ; \mathrm{p}_{\text {intercept }}<0.0001\right)$.

\section{Discussion}

Most of our results agree with the disruptive coloration hypothesis (Cuthill et al., 2005; Merilaita, Lind, 2005; Schaefer, Stobbe, 2006; Stevens et al., 2006). Banded animals (disruptive coloration) use more habitats, occupying places with more varied background colors in comparison with nonbanded, plain colored, animals. Nonetheless, contrary to our predictions, banded and non-banded animals use holdfasts in a similar manner. We observed slightly more animals with disruptive colors than plain animals. In pygmy grasshopper, such difference was attributed to an adaptive advantage for this phenotype in relation to thermoregulation (Ahnesjö, Forsman, 2006). However, the same pattern could be the result of a non-adaptive allele equilibrium in seahorses, if it is genetically determined. Furthermore, if $H$. reidi can change color, as many other seahorses can (Foster, Vincent, 2004), individuals may employ disruptive coloration or background matching strategies in a context-dependent manner.

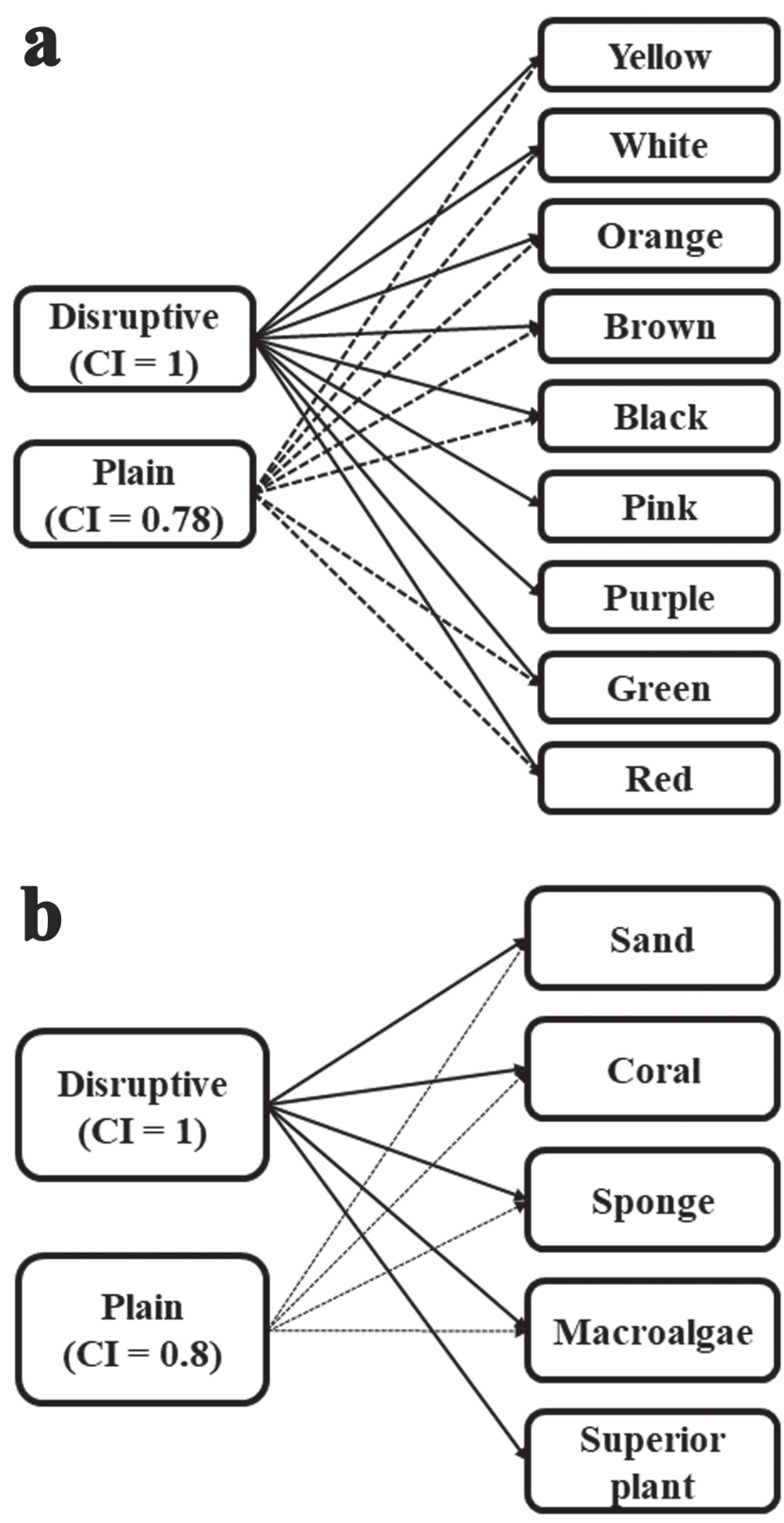

Fig. 3. Connectance of the two seahorse Hippocampus reidi color morphs to the background color (a) and holdfast (b). In parentheses is the value for the connectance index. Sup. Plant $=$ Superior plants.

In general, the observed color distribution in this population agrees with that reported by other studies (Rosa $e t$ al., 2002; Freret-Meurer, Andreata, 2008). The predominance of yellow individuals may reflect carotenoid ingestion in the diet (Segade et al., 2015), as well as a correlation to the availability of this substrate colors, favoring the survival of individuals of certain colors that match the background (Martinez-Cardenas, Purser, 2007). The plain colored seahorses use substrates with the predominant background color of their body, also demonstrating a preference for specific colors. Shrimp juveniles, which mimic parts of algae to camouflage (homochromy and homotipy), have a 

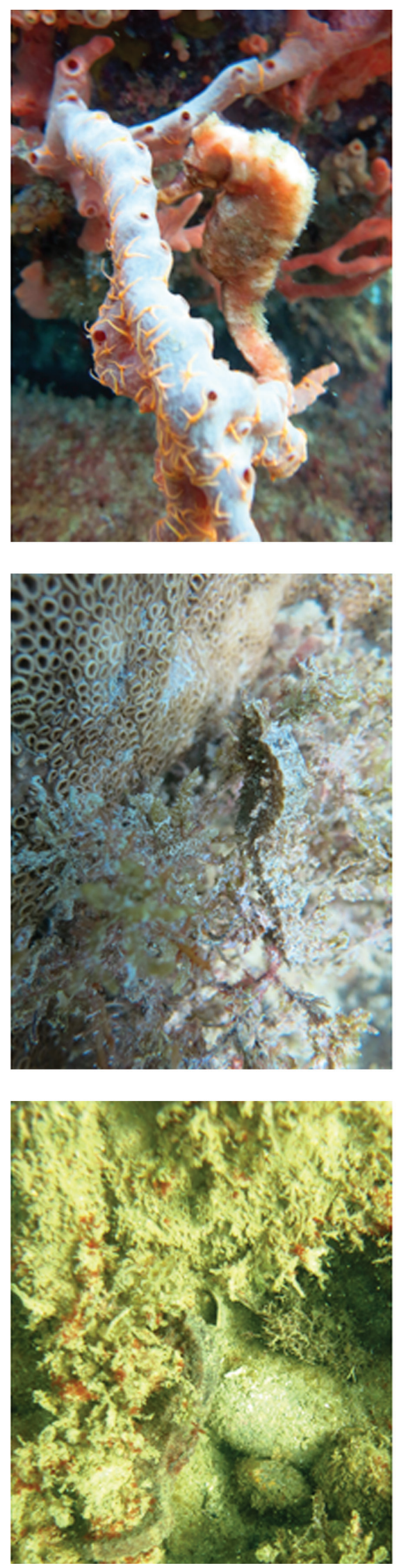

Fig. 4. Plain-colored (Left column) seahorses occupy similar background color, while banded disruptive seahorses (Right column) occupy more diverse habitats. 


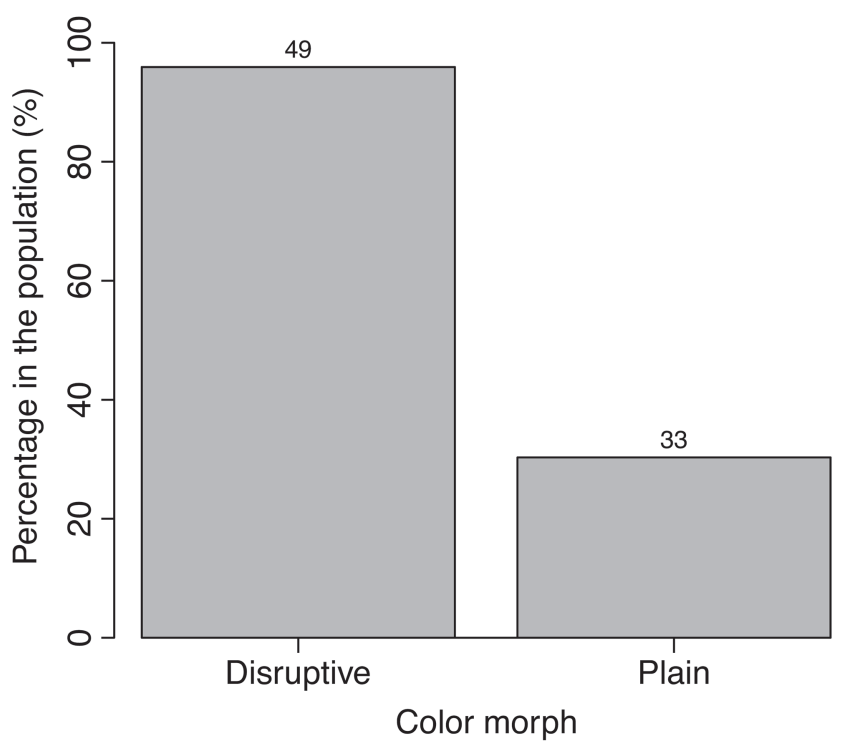

Fig. 5. Percentage of occurrence of individuals of Hippocampus reidi with body-color different from the background color, for each color morph. Tags above each column indicate the absolute number of individuals.

higher dependence on the substrate than their adults, who use disruptive color (Hacker, Madin, 1991). Similarly, Ahnesjö, Forsman (2006) observed that non-striped pygmy grasshoppers had high habitat selectivity possibly because they cannot adapt to different background colors. Sex differences, behavior and habitat use allow potentially disruptive shrimps to evenly occupy different substrates (Duarte et al., 2016; Duarte, Flores, 2017). Thus, animals with disruptive coloration are less dependent or selective on substrates matching their body color.

The efficiency of camouflage is essential to allow a seahorse to avoid predation with the lowest possible energy expenditure. Merilaita, Lind (2005) observed that the resemblance to the background made prey detection by Parus major birds more difficult, but also that the disruptive color was as efficient as homochromy (background matching). Another study using models of Lepidoptera found disruptive coloration to be even more effective than background matching (Merilaita et al., 2001; Cuthill et al., 2005). Animals from complex-colored environments, such as coral reefs (Marshall et al., 2003) or rocky shores (Merilaita, 1998), may acquire disruptive coloration because they become less perceptible, disguising its actual shape and distracting potential predators or prey even in non-matching backgrounds. In a multi-species analysis, Elias et al. (2019) found that the presence of bands in Alpheid shrimps was evolutionarily correlated to a more generalist use of microhabitats. Therefore, disruptive colored animals have high efficiency in predator hiding without the cost of being confined to a single habitat (Merilaita, Lind, 2005). The evidence suggests that, relieved from using homocromy to match the background color, animals such as seahorses could use their body color to communicate and court other individuals.
Other than disruptive coloration, the type of bands found in seahorse could also be interpreted as a form of motiondazzle camouflage (Stevens et al., 2008; Stevens, Merilaita, 2009). This type of strategy suggests that contrasting bands or stripes could affect the estimation of a prey item speed and direction by a predator (Thayer, 1909; Stevens, Merilaita, 2009). However, seahorses are slow-moving and relatively sedentary animals, which makes it unlikely that their bands function as a motion-dazzle camouflage. In addition to disruptive coloration, seahorses also take profit from other skills to evade predators, such as pretending to be dead (FreretMeurer et al., 2017) or changing colors (Foster, Vincent, 2004; Qin et al., 2012;), although stripes or spots do not change (Suzana Ramineli, 2019 pers. obs.). Syngnathidae, in general, possesses high acuity and color vision (Lee, O'Brien, 2011). Therefore, in addition to allowing for effective concealing, disruptive color can assure seahorses opportunities to use their color for other functions, such as mating selection (Oliveira et al., 2010). Some seahorse species use color in communication, including social (Moreau, Vincent, 2004) and sexual encounters (Vincent, 1995; Vincent, Sadler, 1995), by rapidly changing general body tonality, from a darker to a lighter color or by flashing specific body parts such as the male pouch or bright patches.

Some caveats to the applied methods are potentially relevant. Our sampled photos were observed exclusively by the human eye, that could bring imprecisions to color recognition. It is noteworthy that the photos we used represent only an instant in the life of these fish, ignoring their displacement. The angle with which these photos were taken can also influence the result of our analyses since, in the complex reef environment, photos taken in a slightly different angle could cause the animal to be on a different color background. Our sample size, large p-value significance, the use of a reduced number of categories, and a redundancy of visual identifications between two observers allow us to believe our conclusions are consistent, but further studies should consider these factors.

Camouflage is the primary defense mechanism of prey against predators to prevent detection and recognition. However, a mechanism that avoids predation and still allows the exploitation of all available complexity in the environment will bring more advantages than mechanisms that limit the occupation (Merilaita, Lind, 2005; Cuthill et al., 2005; Stevens et al., 2006). Disruptive color offers exactly this advantage. In terms of conservation measures, if seahorse color morphs are genetically determined, habitat diversity in coral reefs, including unbleached corals, will be fundamental for the maintenance of seahorse genetic diversity. Furthermore, these are charismatic and colorful animals, who are also often targeted as ornamental fish for their colors (Rosa et al., 2006). Therefore, the preservation of the marine environment is essential to reduce seahorse threat status. Future experimental studies could test whether the banded pattern indeed confers camouflage in multiple backgrounds in seahorses and test possible trade-offs of the banded pattern (e.g., cost in sexual signaling). 


\section{Acknowledgments}

We would like to thank Gualter Pedrini, from Portal Antrópica, for providing some of the images used in this study, and Hayden Ringrose for English review. This study is also part of projects funded by the Conselho Nacional de Desenvolvimento Científico e Tecnológico (Process Numbers: 408576/2018-9 and 428141/2016-1).

\section{References}

Ahnesjö J, Forsman A. Differential habitat selection by pygmy grasshopper color morphs; interactive effects of temperature and predator avoidance. Evol Ecol. 2006; 20(3):235-57. https://doi.org/10.1007/s10682-006-6178-8

Belo WC, Dias GTM, Dias MS. O fundo marinho da Baía da Ilha Grande, RJ: O relevo submarino e a sedimentação no canal central. Rev Bras Geofís. 2002; 20(1):5-15. http://dx.doi. org/10.1590/S0102-261X2002000100001

Carvalho LN, Zuanon J, Sazima I. The almost invisible league: crypsis and association between minute fishes and shrimps as a possible defence against visually hunting predators. Neotrop Ichthyol. 2006; 4(2):219-24. http://dx.doi.org/10.1590/ S1679-62252006000200008

Chen L, Wang X, Huang B. The Genus Hippocampus-a review on traditional medicinal uses, chemical constituents and pharmacological properties. J Ethnopharmacol. 2015; 162:104-11. https://doi.org/10.1016/j.jep.2014.12.032

Creed JC, Pires DO, Figueiredo MAO. Biodiversidade marinha da Baía da Ilha Grande. Brasília: Ministério do Meio Ambiente; 2007.

Cuthill IC, Stevens M, Sheppard J, Maddocks T, Párraga CA, Troscianko TS. Disruptive coloration and background pattern matching. Nature. 2005; 434(7029):72-74. https://doi. org/10.1038/nature03312

Dias TLP, Rosa IL. Habitat preferences of a seahorse species, Hippocampus reidi (Teleostei: Syngnathidae) in Brazil. Aqua. 2003; 6(4):165-76. Available from: http://www.aquaaquapress.com/pdf/6(4)_Hippocampus\%20reidi.pdf

Duarte RC, Flores AAV. Morph-specific habitat and sex distribution in the caridean shrimp Hippolyte obliquimanus. J Mar Biol Assoc U K. 2017; 97(2):235-42. https://doi. org/10.1017/S0025315416000230

Duarte RC, Stevens M, Flores AAV. Shape, colour plasticity, and habitat use indicate morph-specific camouflage strategies in a marine shrimp. BMC Evol Biol. 2016; 16(218):1-15. https:// doi.org/10.1186/s12862-016-0796-8

Ebenstein D, Calderon C, Troncoso OP, Torres FG. Characterization of dermal plates from armored catfish Pterygoplichthys pardalis reveals sandwich-like nanocomposite structure. J Mech Behav Biomed Mater. 2015; 45:175-82. https://doi. org/10.1016/j.jmbbm.2015.02.002

Elias MAM, Anker A, Gawryszewski FM. Microhabitat use and body size drive the evolution of colour patterns in snapping shrimps (Decapoda: Alpheidae: Alpheus). Biol J Linn Soc Lond. 2019; 128(4):blz152. https://doi.org/10.1093/ biolinnean/blz152

Endler JA. Progressive background in moths, and a quantitative measure of crypsis. Biol J Linn Soc Lond. 1984; 22(3):187231. https://doi.org/10.1111/j.1095-8312.1984.tb01677.x
Figueiredo JD, Menezes NA. Manual de peixes marinhos do sudeste do Brasil. São Paulo: Universidade de São Paulo; 1985.

Foster SJ, Vincent ACJ. Life history and ecology of seahorses: implications for conservation and management. J Fish Biol. 2004; 65(1):1-61. https://doi.org/10.1111/j.00221112.2004.00429.x

Freret-Meurer NV, Andreata JV, Alves MAS. Seahorse fingerprints: a new individual identification technique. Environ Biol Fish. 2013; 96(12):1399-405. https://doi. org/10.1007/s10641-013-0118-6

Freret-Meurer NV, Andreata JV. Field studies of a brazilian seahorse population, Hippocampus reidi Ginsburg, 1933. Braz Arch Biol Technol. 2008; 51(4):543-51. http://dx.doi. org/10.1590/S1516-89132008000400012

Freret-Meurer NV, Fernandez TC, Lopes DA, Vaccani AC, Okada NB. Thanatosis in the Brazilian seahorse Hippocampus reidi Ginsburg, 1933 (Teleostei: Syngnathidae). Acta Ethol. 2017; 20(1):81-84. https://doi.org/10.1007/s10211-016-0247-y

Fretwell SD. On territorial behavior and other factors influencing habitat distribution in birds. Acta Biotheor. 1969; 19(1):4552. https://doi.org/10.1007/BF01601955

Hacker SD, Madin LP. Why habitat architecture and color are important to shrimps living in pelagic Sargassum: use of camouflage and plant-part mimicry. Mar Ecol Prog Ser. 1991; 70(2):143-55. Available from: https://www.jstor.org/ stable/24816770

Itoi S, Yoshikawa S, Asahina K, Suzuki M, Ishizuka K, Takimoto N, Mitsuoka R et al. Larval pufferfish protected by maternal tetrodotoxin. Toxicon. 2014; 78:35-40. https://doi. org/10.1016/j.toxicon.2013.11.003

Kennedy M, Gray RD. Can ecological theory predict the distribution of foraging animals? A critical analysis of experiments on the ideal free distribution. Oikos. 1993; 68(1):158-66. https://doi.org/10.2307/3545322

Lee HR, O'Brien KMB. Morphological and behavioral limit of visual resolution in temperate (Hippocampus abdominalis) and tropical (Hippocampus taeniopterus) seahorses. Vis Neurosci. 2011; 28(4):351-60. https://doi.org/10.1017/ S0952523811000149

Leone MF. Testes empíricos sobre a ocorrência diferencial de listras em duas espécies de Monodelphis (Didelphidae: Mammalia) e seu papel como coloração disruptiva e na evasão de predadores. [Master Dissertation]. Vitória: Universidade Federal do Espírito Santo; 2014.

Lourie SA, Pollom RA, Foster SJ. A global revision of the seahorses Hippocampus rafinesque 1810 (Actinopterygii: Syngnathiformes): Taxonomy and biogeography with recommendations for further research. Zootaxa. 2016; 4146(1):1-66. http://dx.doi.org/10.11646/zootaxa.4146.1.1

Lourie SA, Vincent ACJ, Hall HJ. Seahorses: an identification guide to the world's species and their conservation. London: Project Seahorse; 1999.

Loy A, Hofmann H, Cook D. Model choice and diagnostics for linear mixed-effects models using statistics on street corners. J Comp Graphic Stat. 2017; 26(3):478-92. https://doi.org/10.10 80/10618600.2017.1330207

Marshall NJ, Jennings K, McFarland WN, Loew ER, Losey GS. Visual biology of Hawaiian coral reef fishes. II. Colors of Hawaiian coral reef fish. Copeia. 2003; 2003(3):455-66. https://doi.org/10.1643/01-055 
Martinez-Cardenas L, Purser GJ. Effect of tank colour on Artemia ingestion, growth and survival in cultured early juvenile potbellied seahorses (Hippocampus abdominalis). Aquaculture. 2007; 264(1-4):92-100. https://doi.org/10.1016/j. aquaculture.2006.12.045

Merilaita S. Crypsis through disruptive coloration in an isopod. Proc R Soc Lond B Biol Sci. 1998; 265(1401):1059-64. https:// doi.org/10.1098/rspb.1998.0399

Merilaita S, Lind J. Background-matching and disruptive coloration, and the evolution of cryptic coloration. Proc R Soc Lond B Biol Sci. 2005; 272(1563):665-70. https://doi. org/10.1098/rspb.2004.3000

Merilaita S, Tuomi J, Jormalainen V. Optimization of cryptic coloration in heterogeneous habitats. Biol J Linn Soc. 1999; 67(2):151-61. https://doi.org/10.1111/j.1095-8312.1999. tb01858.x

Merilaita S, Lyytinen A, Mappes J. Selection for cryptic coloration in a visually heterogeneous habitat. Proc R Soc Lond B Biol Sci. 2001; 268(1479):1925-29. https://doi.org/10.1098/ rspb.2001.1747

Ministério do Meio Ambiente (MMA). Áreas prioritárias para a conservação, utilização sustentável e repartição de benefícios da biodiversidade brasileira ou áreas prioritárias para a biodiversidade. Brasília; 2003.

Moreau MA, Vincent ACJ. Social structure and space use in a wild population of the australian short-headed seahorse Hippocampus breviceps Peters, 1869. Mar Freshw Res. 2004; 55(3):231-39. https://doi.org/10.1071/MF03159

Oliveira TPR, Castro ALC, Rosa IL. Novel sex-related characteristics of the longsnout seahorse Hippocampus reidi Ginsburg, 1933. Neotrop Ichthyol. 2010; 8(2):373-78. http:// dx.doi.org/10.1590/S1679-62252010000200017

Perante NC, Pajaro MG, Meeuwig JJ, Vincent ACJ. Biology of a seahorse species, Hippocampus comes in the central Philippines. J Fish Biol. 2002; 60(4):821-37. https://doi. org/10.1111/j.1095-8649.2002.tb02412.x

Pinto-Joventino FK, Lianza S, Johnsson RMF. Pesca artesanal na Baía de Ilha Grande, no Rio de Janeiro: conflitos com unidades de conservação e novas possibilidades de gestão. Polit Soc. 2013; 12(23):159-82. https://doi.org/10.5007/2175$7984.2013 \mathrm{v} 12 \mathrm{n} 23 \mathrm{p} 159$

Qin G, Lin Q, Gu N, Lin J, Huang L. Effect of broodstock origin, background and substrate color on skin coloration of threespotted seahorses Hippocampus trimaculatus Leach, 1814. J Exp Mar Biol Ecol. 2012; 416-417:129-34. https://doi. org/10.1016/j.jembe.2012.02.007

Ramasamy RA, Allan BJM, McCormick MI. Plasticity of escape responses: prior predator experience enhances escape performance in a coral reef fish. PLoS ONE. 2015; 10(8):e0132790. https://doi.org/10.1371/journal.pone.0132790

Rosa IL, Dias TL, Baum JK. Threatened fishes of the world: Hippocampus reidi Ginsburg, 1933 (Syngnathidae). Environ Biol Fish. 2002; 64(4):378

Rosa IL, Sampaio CLS, Barros AT. Collaborative monitoring of the ornamental trade of seahorses and pipefishes (Teleostei: Syngnathidae) in Brazil: Bahia State as a case study. Neotrop Ichthyol. 2006; 4(2):247-52. http://dx.doi.org/10.1590/S167962252006000200010
Rouse GW, Stiller J, Wilson NG. First live records of the ruby seadragon (Phyllopteryx dewysea, Syngnathidae). Mar Biodivers Rec. 2017; 10(2):1-4. https://doi.org/10.1186/ s41200-016-0102-x

Schaefer HM, Stobbe N. Disruptive coloration provides camouflage independent of background matching. Proc R Soc Lond B Biol Sci. 2006; 273(1600):2427-32. https://doi.org/10.1098/ rspb.2006.3615

Segade A, Robaina L, Otero-Ferrer F, Romero JG, Domínguez LM. Effects of the diet on seahorse (Hippocampus hippocampus) growth, body colour and biochemical composition. Aquac Nutr. 2015; 21(6):807-13. https://doi.org/10.1111/anu.12202

Short G, Smith R, Motomura H, Harasti D, Hamilton H. Hippocampus japapigu, a new species of pygmy seahorse from Japan, with a redescription of $H$. pontohi (Teleostei, Syngnathidae). ZooKeys. 2018; 779:27-49. https://dx.doi org/10.3897\%2Fzookeys.779.24799

Silveira RB, Siccha-Ramirez R, Silva JRS, Oliveira C. Morphological and molecular evidence for the occurrence of three Hippocampus species (Teleostei: Syngnathidae) in Brazil. Zootaxa. 2014; 3861(4):317-32. http://dx.doi.org/10.11646/ zootaxa.3861.4.2

Stevens M. Color change, phenotypic plasticity, and camouflage. Front Ecol Evol. 2016; 4(51):1-10. https://doi.org/10.3389/ fevo.2016.00051

Stevens M, Cuthill IC, Windsor AMM, Walker HJ. Disruptive contrast in animal camouflage. Proc R Soc Lond B Biol Sci. 2006; 273(1600):2433-38. https://doi.org/10.1098/ rspb.2006.3614

Stevens M, Merilaita S. Animal camouflage: current issues and new perspectives. Philos Trans R Soc Lond B Biol Sci. 2009; 364(1516):423-27. https://doi.org/10.1098/rstb.2008.0217

Stevens M, Yule DH, Ruxton GD. Dazzle coloration and prey movement. Proc R Soc Lond B Biol Sci. 2008; 275(1651):263943. https://doi.org/10.1098/rspb.2008.0877

Thayer GH. Concealing-coloration in the Animal Kingdom: being a summary of Abbott H. Thayer's Discoveries. New York: Macmillan Company; 1909.

Van Der Laan JD, Hogeweg P. Predator-prey coevolution: interactions across different timescales. Proc R Soc Lond B Biol Sci. 1995; 259(1354):35-42. https://doi.org/10.1098/ rspb.1995.0006

Vincent ACJ. A role for daily greetings in maintaining seahorse pair bonds. Anim Behav. 1995; 49(1):258-60. https://doi. org/10.1016/0003-3472(95)80178-2

Vincent ACJ, Sadler LM. Faithful pair bonds in wild seahorses, Hippocampus whitei. Anim Behav. 1995; 50(6):1557-59. https://doi.org/10.1016/0003-3472(95)80011-5

Webster RJ, Hassall C, Herdman CM, Godin JGJ, Sherratt TN. Disruptive camouflage impairs object recognition. Biol Lett. 2013; 9(6):20130501. https://doi.org/10.1098/rsb1.2013.0501

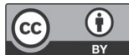

Submitted April 8, 2019 Accepted November 12, 2019 by Fernando Gibran 